\title{
INTERVENSI GAYA HIDUP TERHADAP PENCEGAHAN OBESITAS PADA REMAJA DI SMP KHADIJAH KOTA MAKASSAR
}

\author{
INTERVENTION OF LIFE STYLE ON OBESITY PREVENTION IN ADOLESCENT IN SMP KHADIJAH \\ CITY OF MAKASSAR
}

\author{
Rosdiana \\ Fakultas Kesehatan Masyarakat, Universitas Indonesia Timur, Makassar \\ Email Korespondensi : Rosdiana_lia83@yahoo.com
}

\begin{abstract}
Abstrak
Overweight telah menjadi pandemi global di seluruh dunia dan dinyatakan oleh World Health Organization (WHO) sebagai masalah kesehatan kronis terbesar. Penelitian ini untuk bertujuan untuk membuktikan pengaruh variabel independen intervensi gaya hidup terhadap variabel dependen pencegahan obesitas. Jenis Penelitian ini adalah Quasy Eksperiment dengan pre-test and posttest. Populasi pada penelitian ini semua siswa SMP Khadijah Kota Makassar yang tergolong overweight dan obesitas. Sedangkan Sampel sebanyak 14 Siswa. Hasil penelitian diperoleh bahwa ada perubahan status gizi siswa (1 normal) tetapi tidak ada pengaruh secara bermakna antara intervensi gaya hidup terhadap status gizi baik pada kelompok perlakuan $(\rho=0,107)$ maupun kelompok kontrol $(\rho=0,081)$. Sedangkan untuk pola makan dan asupan gizi ada perubahan pola makan dan asupan gizi siswa (3 baik) tetapi tidak ada pengaruh secara bermakna antara intervensi gaya hidup terhadap pola makan dan asupan gizi siswa baik pada kelompok perlakuan $(\rho=1)$ maupun kelompok kontrol $(\rho=0,060)$. Pada aktivitas fisik tidak ada perubahan dan pengaruh yang bermakna antara intervensi gaya hidup baik pada kelompok perlakuan maupun kelompok kontrol dengan nilai $(\rho$ $=0,59$ ). Penelitian ini menyimpulkan bahwa intervensi gaya hidup dapat memberikan perubahan yang cukup terhadap status gizi siswa, pola makan dan asupan gizinya walaupun dari hasil analisis statistik tidak memberikan perubahan yang bermakna secara signifikan. Sedangkan untuk aktivitas fisik, intervensi gaya hidup belum dapat memberikan prubahan yang cukup dan dari hasil analisis statistik juga menunjukkan tidak ada perubahan yang bermakna secara signifikan. Adapun saran yang terkait dengan penelitian ini adalah sebaiknya ada kerja sama bagi semua pihak dalam mengupayakan pencegahan terhadap kejadian obesitas pada remaja dengan mengubah gaya hidupnya yang meliputi pola makan dan aktivitas fisik.
\end{abstract}

Kata Kunci : Obesitas, Gaya Hidup

\begin{abstract}
Overweight has become a global pandemic worldwide and declared by the World Health Organization (WHO) as the biggest chronic health problem. This study aims to prove the effect of independent variables of lifestyle intervention on the dependent variable of obesity prevention. This type of research is Quasy Experiment with pre-test and post-test. The population in this study are all students of SMP Khadijah Kota Makassar which is classified as overweight and obesity. While the sample of 14 students. The result showed that there was a change of nutritional status of students (1 normal) but there was no significant influence between lifestyle intervention on nutritional status in both treatment group $(\rho=0,107)$ and control group $(\rho=0,081)$. As for the diet and nutritional intake there are changes in diet and nutritional intake of students (3 good) but there is no significant effect between lifestyle intervention on diet and nutritional intake of students both in treatment group ( $\rho=1)$ and control group $(\rho=0.060)$. In physical activity there was no significant change and influence between lifestyle intervention in both treatment group and control group with value $(\rho=0,59)$. The study concluded that lifestyle intervention could provide sufficient change to the nutritional status of students, diet and nutritional intake even though the results of statistical analysis did not provide significant changes significantly. While for physical activity, lifestyle intervention has not been able to provide sufficient change and from the results of statistical analysis also showed no significant change significantly. The advice related to this research is there should be cooperation for all parties in trying to prevent the obesity in adolescents by changing lifestyle that includes diet and physical activity.
\end{abstract}

Keywords: Obesity, Lifestyle 


\section{PENDAHULUAN}

Overweight telah menjadi pandemi global di seluruh dunia dan dinyatakan oleh World Health Organization (WHO) sebagai masalah kesehatan kronis terbesar. Obesitas dan Overweight atau yang biasa dikenal sebagai kegemukan merupakan masalah yang cukup merisaukan dikalangan remaja. Peningkatan prevalensi overweight dan obesitas terjadi baik pada negara-negara maju maupun negara berkembang $\stackrel{1}{ }$.

Menurut Word Health Organization (WHO) 2014 menyatakan angka obesitas didunia sebesar 11,9\% dan lebih dari 1.4 milyar remaja yang berusia 20 tahun atau lebih menderita Overweight, dan penderita obesitas sebanyak 200 juta adalah remaja laki-laki dan 300 juta adalah remaja perempuan. Overweight dan obesitas adalah resiko terbesar penyebab kematian global. Sekitar 3.4 juta remaja meninggal setiap tahunnya karena kedua hal tesebut. Hal lain yang harus diperhatikan adalah $44 \%$ penderita diabetes, $23 \%$ penderita jantung dan antara $7-41 \%$ penderita kanker berhubungan dengan Overweight dan obesitas $\stackrel{2}{\text {. }}$

Penelitian yang dilakukan oleh Guo et al, di Cina menemukan bahwa prevalensi Overweight pada anak dan remaja adalah sebesar $15,3 \%$ dan obesitas sebesar 6,4\%. Penelitian oleh National Health and Nutrition Examination Survei (NHANES) menunjukkan prevalensi obesitas di Amerika Serikat tahun 2011-2012 pada orang dewasa usia $\geq 20$ tahun adalah $34.9 \%$ serta anak dan remaja usia 2-19 tahun adalah 16.9\%ํㅜㅇ.

Peningkatan prevalensi obesitas juga terjadi di negara berkembang seperti Indonesia. Data Riset Kesehatan Dasar (Riskesdas) tahun 2013 menunjukkan bahwa secara nasional prevalensi gemuk pada remaja umur 13-15 tahun di Indonesia sebesar 10,8\%, terdiri dari $8,3 \%$ gemuk dan 2,5\% sangat gemuk. Hasil riset kesehatan dasar memperlihatkan peningkatan prevalensi obesitas pada remaja di Indonesia dari 1,4\% (2007) menjadi 7,3\% $(2013)^{4}$.

Menurut data dari hasil Riskesdas 2013 di Sulawesi Selatan, prevalensi obesitas umum untuk laki-laki sebesar $18,5 \%$ dan perempuan $31,5 \%$. Perubahan gaya hidup yang cepat termasuk pola makan dan aktivitas telah menyebabkan peningkatan prevalensi anak overweight dan obesitas (5-19 tahun) di negara berkembang. Gaya hidup masyarakat Indonesia saat ini, khususnya pada remaja cenderung mengikuti gaya hidup negara barat yang cenderung konsumtif dengan pemilihan makanan siap saji yang mengadung tinggi lemak. Selain pola makan yang tinggi lemak, gaya hidup ini juga cenderung sedikit beraktivitas berat dan lebih sering melakukan aktifitas ringan seperti menonton tv, bermain game, dan sebagainya ${ }^{5}$.

Overweight dan obesitas saat remaja merupakan faktor risiko penyebab penyakit kronis dan berhubungan dengan peningkatan risiko obesitas dimasa dewasa sebesar 50\%-80\%. Kelebihan berat badan dapat dicegah dengan mengubah pola hidup sehat seperti mengubah pola makan dan meningkatkan aktivitas fisik serta melakukan upaya peningkatan kesehatan di masyarakat seperti memberikan pendidikan kesehatan sebagai upaya tindakan preventif dan promotif.

Menurut hasil penelitian Nurmasyita (2015) menyatakan bahwa pendidikan gizi pada remaja kelebihan berat badan menurunkan IMT remaja melalui peningkatan pengetahuan tentang gizi. Pengetahuan gizi remaja kelebihan berat badan dapat menurunkan Tingkat Kecukupan Energi, Tingkat Kecukupan Protein, persentase asupan karbohidrat, persentase asupan lemak dan meningkatkan asupan serat. Konsumsi zat gizi yang sesuai dengan kebutuhan remaja kelebihan berat badan akan berdampak pada penurunan IMT remaja kelebihan berat badan sehingga remaja memiliki kondisi gizi/ status gizi yang lebih baik $\underline{6}$.

Lebih lanjut telah dijelaskan dalam penelitian (Nurmasyita, 2015) bahwa kelebihan berat badan dapat dicegah dengan mengubah pola hidup sehat seperti mengubah pola makan dan meningkatkan aktivitas fisik serta melakukan upaya peningkatan kesehatan di masyarakat seperti memberikan pendidikan kesehatan sebagai upaya tindakan preventif dan promotif. Salah satu bentuk dari intervensi pendidikan kesehatan itu adalah dengan melakukan konseling ${ }^{6}$. 
Perubahan gizi pada remaja jika tidak diupayakan perbaikannya akan mempengaruhi kualitas masyarakat di masa mendatang. Gambaran overweight di masa sekarang berdampak besar pada gambaran obesitas di masa mendatang, sehingga perlu dicari informasi dan perlakuan (intervensi) mengenai overweight dan obesitas remaja dengan cara pencegahan melalui Intervensi gaya hidup.

Masalah obesitas banyak dialami oleh beberapa golongan di masyarakat, antara lain balita, anak usia sekolah, remaja, dewasa dan orang lanjut usia. Angka prevalensi obesitas di atas baik pada anak-anak maupun remaja dan orang dewasa sudah merupakan tanda peringatan bagi pemerintah dan masyarakat luas bahwa obesitas dan segala implikasinya sudah merupakan ancaman yang serius bagi masyarakat Indonesia khususnya di Kota-Kota besar ${ }^{7}$.

Dua pertiga anak usia sekolah adalah anak sekolah yang separuh waktu berada di sekolah sehingga promosi kesehatan baik dilaksanakan. CDC (2010) menyatakan bahwa sekolah berperan penting dalam memperbaiki perilaku makan dan aktivitas fisik remaja dalam mencegah atau menurunkan prevalensi overweight atau obesitas ${ }^{-}$.

Tujuan utama penanggulangan overweight dan obesitas pada anak dan remaja adalah mencapai berat badan normal dengan mempertimbangkan pertumbuhan dan perkembangan. Perubahan perilaku efektif dalam penanggulangan obesitas yang terdiri dari perubahan perilaku, modifikasi diet dan modifikasi kebiasaan aktifitas fisik, olehnya itu penelitian ini bertujuan untuk untuk membuktikan pengaruh intervensi gaya hidup terhadap pencegahan obesitas pada remaja.

\section{METODE}

Desain penelitian yang digunakan adalah Quasy Eksperiment dengan pre-test and post. Kelompok perlakuan diberikan intervensi pendidikan gizi selama waktu yang telah ditentukan melalui penerapan Konseling Modifikasi Gaya Hidup dengan memberikan panduan gaya hidup sehat berupa PUGS dan leaflet pada remaja dengan obesitas, sedangkan kontrol tidak diberikan intervensi, hanya berupa leaflet. Remaja pada kelompok perlakuan dan kelompok kontrol dilakukan pengukuran IMT/Umur (Berat Badan/Tinggi Badan) sebelum dan setelah intervensi. Penelitian ini dilakukan di SMP Khadijah Kota Makassar dan dilaksanakan pada tanggal 17 Mei sampai dengan 17 Juni 2017. Populasi dalam penelitian ini adalah semua siswa SMP Khadijah Kota Makassar yang tergolong overweight dan obesitas dari kelas VII berjumlah 7 siswa dan kelas VIII berjumlah 9 siswa, sehingga jumlah seluruh populasi adalah 16 siswa. Sampel dalam penelitian ini adalah sebagian siswa kelas VII dan VIII SMP Khadiah Kota Makassar. Teknik pengambilan sampel dilakukan dengan cara random sampling sebesar 16 Siswa. Penelitian ini menggunakan analisis data uji non parametrik MannWhitne, oleh karena data tidak berdistribusi normal.

\section{HASIL}

\section{Tabel 1}

Perbandingan Perubahan Status Gizi Siswa yang Tergolong Overweight dan Obesitas Sebelum dan Setelah Intervensi di SMP Khadijah Kota Makassar Tahun 2017

\begin{tabular}{|c|c|c|c|c|c|c|c|}
\hline \multirow{3}{*}{ Variabel } & \multicolumn{6}{|c|}{$\begin{array}{c}\text { Perubahan Status Gizi } \\
\text { Kelompok }\end{array}$} & \multirow{3}{*}{$\begin{array}{l}\text { Nilai } \\
\boldsymbol{\rho}\end{array}$} \\
\hline & \multicolumn{3}{|c|}{ Perlakuan $(n=7)$} & \multicolumn{3}{|c|}{ Kontrol $(n=7)$} & \\
\hline & $\begin{array}{l}\text { Mean } \\
\text { Rank }\end{array}$ & $\begin{array}{l}\text { Min/ } \\
\text { Max }\end{array}$ & Med & $\begin{array}{l}\text { Mean } \\
\text { Rank }\end{array}$ & $\begin{array}{l}\text { Min/ } \\
\text { Max }\end{array}$ & Med & \\
\hline $\begin{array}{l}\text { Status Gizi } \\
\text { (Pre) }\end{array}$ & 9,00 & $1 / 2$ & 2 & 6,00 & $1 / 2$ & 1 & 0,10 \\
\hline $\begin{array}{l}\text { Status Gizi } \\
\text { (Post) }\end{array}$ & 9,21 & $1 / 3$ & 2 & 5,79 & $1 / 2$ & 1 & 0,08 \\
\hline
\end{tabular}

Tabel 1 menunjukkan bahwa nilai mean status gizi siswa pada kelompok perlakuan sebelum intervensi yaitu 9,00 dan setelah intervensi yaitu 9,21 serta hasil uji statistik sebesar nilai $\rho=0,107(<0,05)$ ini menunjukkan tidak ada perubahan bermakna pada status gizi dengan intervensi gaya hidup pada kelompok perlakuan. Sedangkan pada kelompok kontrol didapatkan nilai mean status gizi siswa sebelum intervensi yaitu 6,00 dan setelah intervensi 5,79 serta hasil uji statistik sebesar nilai $\rho=0,081 \quad(<0,05)$ ini juga menunjukkan tidak ada perubahan bermakna pada status gizi dengan intervensi 
gaya hidup pada kelompok kontrol.

Tabel 2.

Perbandingan Perubahan Asupan Gizi Siswa yang Tergolong Overweight dan Obesitas Sebelum dan Setelah Intervensi di SMP Khadijah Kota Makassar Tahun 2017

\begin{tabular}{|c|c|c|c|c|c|c|c|}
\hline \multirow[b]{3}{*}{ Variabel } & \multicolumn{6}{|c|}{$\begin{array}{c}\text { Perubahan Asupan Gizi } \\
\text { Kelompok }\end{array}$} & \multirow{3}{*}{$\begin{array}{c}\text { Nilai } \rho \\
\text { Mann } \\
\text { Whitney }\end{array}$} \\
\hline & \multicolumn{3}{|c|}{ Perlakuan $(n=7)$} & \multicolumn{3}{|c|}{ Kontrol $(n=7)$} & \\
\hline & $\begin{array}{c}\text { Mea } \\
\mathrm{n} \\
\text { Ran } \\
\mathrm{k}\end{array}$ & $\begin{array}{l}\text { Min/ } \\
\text { Max }\end{array}$ & Med & $\begin{array}{c}\text { Mea } \\
n \\
\text { Ran } \\
k\end{array}$ & $\begin{array}{l}\text { Min/ } \\
\text { Max }\end{array}$ & Med & \\
\hline $\begin{array}{c}\text { Asupan } \\
\text { Gizi (Pre) } \\
\text { Asupan }\end{array}$ & 7,50 & $1 / 2$ & 1 & 7,50 & $1 / 2$ & 1 & 1 \\
\hline Gizi (Post) & 9,00 & $1 / 2$ & 1 & 6,00 & $1 / 2$ & 1 & 0,06 \\
\hline
\end{tabular}

Pada table 2 menampilkan bahwa nilai mean asupan gizi siswa pada kelompok perlakuan sebelum intervensi yaitu 7,50 dan setelah intervensi yaitu 9,00 serta serta hasil uji statistik sebesar nilai $\rho=1(<0,05)$ ini menunjukkan tidak ada perubahan bermakna pada asupan gizi siswa dengan intervensi gaya hidup pada kelompok perlakuan. Sedangkan pada kelompok kontrol didapatkan nilai mean asupan gizi siswa sebelum intervensi yaitu 7,50 dan setelah intervensi 6,00 serta hasil uji statistik sebesar nilai $\rho=0,060(<0,05)$ ini juga menunjukkan tidak ada perubahan bermakna pada asupan gizi siswa dengan intervensi gaya hidup pada kelompok kontrol.

\section{Tabel 3.}

Perbandingan Perubahan Aktivitas Fisik Siswa yang Tergolong Overweight dan Obesitas Sebelum dan Setelah Intervensi di SMP Khadijah Kota Makassar Tahun 2017

\begin{tabular}{|c|c|c|c|c|c|c|c|}
\hline \multirow[b]{3}{*}{ Variabel } & \multicolumn{6}{|c|}{$\begin{array}{c}\text { Perubahan Aktivitas Fisik } \\
\text { Kelompok }\end{array}$} & \multirow{3}{*}{$\begin{array}{c}\text { Nilai p } \\
\text { Mann } \\
\text { Whitney }\end{array}$} \\
\hline & \multicolumn{3}{|c|}{ Perlakuan $(n=7)$} & \multicolumn{3}{|c|}{ Kontrol $(n=7)$} & \\
\hline & $\begin{array}{c}\text { Mea } \\
\mathrm{n} \\
\text { Ran } \\
\mathrm{k}\end{array}$ & $\begin{array}{l}\operatorname{Min} / \\
\operatorname{Max}\end{array}$ & Med & $\begin{array}{c}\text { Mea } \\
\mathrm{n} \\
\text { Ran } \\
\mathrm{k}\end{array}$ & $\begin{array}{l}\text { Min/ } \\
\operatorname{Max}\end{array}$ & Med & \\
\hline $\begin{array}{l}\text { Aktivitas } \\
\text { Fisik (Pre) }\end{array}$ & 8,00 & $1 / 2$ & 1 & 7,00 & $1 / 2$ & 1 & 0,59 \\
\hline $\begin{array}{l}\text { Aktvitas } \\
\text { Fisik (Post) }\end{array}$ & 8,00 & $1 / 2$ & 1 & 7,00 & $1 / 2$ & 1 & 0,59 \\
\hline
\end{tabular}

Tabel 3 menunjukkan bahwa nilai mean aktivitas fisik siswa pada kelompok perlakuan sebelum dan setelah intervensi yaitu 8,00, sedangkan pada kelompok kontrol didapatkan nilai mean aktivitas fisik siswa sebelum dan setelah intervensi yaitu 7,00. Hasil uji statistik sebelum dan setelah intervensi gaya hidup pada kedua kelompok didapatkan nilai $\rho=0,591(<0,05)$, artinya tidak ada perubahan bermakna pada aktivitas fisik siswa antara kedua kelompok.

\section{PEMBAHASAN}

Pada pengukuran pre kelompok perlakuan terdapat siswa dengan status gizi overweight sebanyak 6 orang dan obesitas sebanyak 1 orang, sedangkan pada kelompok kontrol terdapat status gizi overweight sebanyak 3 orang dan obesitas sebanyak 4 orang. Setelah dilakukan intervensi, terdapat perubahan status gizi siswa hanya pada satu kelompok, yaitu pada kelompok perlakuan dengan status gizi normal sebanyak 1 orang, overweight sebanyak 5 orang dan obesitas sebanyak 1 orang, sedangkan pada kelompok kontrol tidak terdapat perubahan.

Hal ini tidak sejalan dengan penelitian Nurmasyita (2015) yang menyatakan bahwa terdapat perbedaan rerata IMT yang bermakna sebelum dan sesudah pendidikan gizi pada kelompok perlakuan dan kontrol. Pendidikan gizi diharapkan menjadi salah satu solusi untuk meningkatkan status gizi dan derajat kesehatan remaja dengan cara menyampaikan teori dan informasi tentang gizi pada sasaran pendidikan seperti remaja dengan metode belajar mengajar ${ }^{6}$.

Namun disisi lain, hasil penelitian ini sejalan dengan penelitian de Ferranti (2016) yang menyatakan bahwa persentil IMT baik grup penyuluhan kelompok maupun individu sesudah pendidikan gizi yang dilaksanakan selama 6 bulan tidak terdapat perbedaan penurunan yang bermakna, hal ini dibutuhkan dengan komitmen dan motivasi yang tinggi ${ }^{3}$. Pada penelitian Nicholls (2014) menunjukkan hasil yang sama tidak terdapat perubahan yang signifikan dalam tingkat kelebihan berat badan selama periode dua tahun baik untuk kelompok maupun untuk mereka yang telah mendapatkan konsultasi tunggal ${ }^{9}$.

Tidak adanya perubahan secara bermakna dari hasil uji statistik dalam penelitian ini bisa saja disebabkan oleh karena waktu intervensi gaya hidup yang telah dilakukan relatif singkat yaitu hanya selama 6 kali per- 
temuan dalam 1 bulan kepada siswa yang tergolong overweight dan obesitas sehingga peneliti belum dapat mengontrol secara total gaya hidup siswa.

Akan tetapi, meskipun waktu intervensi berlangsung dalam waktu yang relatif lama, gaya hidup siswa ini tetap tidak bisa dikontrol total oleh peneliti dikarenakan siswa tidak selamanya berada di sekolah. Dengan kata lain, siswa ini akan pulang ke rumahnya yang otomatis gaya hidupnya tidak bisa terlepas dari faktor gaya hidup keluarganya sendiri.

Dalam penelitian ini intervensi gaya hidup merupakan salah satu bentuk edukasi kesehatan bidang gizi yang sangat penting untuk merubah perilaku yang tidak sesuai dengan kaidah gizi. Intervensi pendidikan gizi pada remaja kelebihan berat badan diharapkan dapat meningkatkan pengetahuan gizi dan kemudian pengetahuan gizi yang dimiliki dapat berpengaruh terhadap perilaku dalam memilih dan mengkonsumsi makanan yang memenuhi syarat kebutuhan zat gizi individu $\underline{10}$.

Konsumsi zat gizi yang sesuai dengan kebutuhan remaja kelebihan berat badan akan berdampak pada penurunan IMT remaja kelebihan berat badan sehingga remaja memiliki kondisi gizi/status gizi yang lebih baik.

Asupan gizi siswa pada kelompok perlakuan dan kontrol sebelum intervensi terdapat yang tidak normal masing-masing sebanyak 7 orang. Setelah dilakukan intervensi, terdapat perubahan asupan gizi siswa hanya pada satu kelompok, yaitu pada kelompok perlakuan dengan asupan gizi normal sebanyak 3 orang dan tidak normal sebanyak 4 orang, sedangkan pada kelompok kontrol tidak terdapat perubahan. Hal tersebut menunjukkan bahwa tidak ada pengaruh secara bermakna antara intervensi gaya hidup terhadap asupan gizi siswa baik pada kelompok perlakuan maupun kelompok kontrol. Tidak adanya perubahan yang bermakna tersebut pada dasarnya sama dengan uraian sebelumnya pada pembahasan pola makan, yaitu karena persoalan waktu intervensi yang relatif singkat.

Setiap pertemuan terhadap siswa, peneliti mem- berikan materi panduan asupan gizi yang terangkum dalam media leaflet dan modul PUGS. Hal tersebut merupakan upaya intervensi yang dilakukan dengan harapan siswa ini akan mengontrol pola makannya yang berdampak pada asupan gizinya. Adapun rata-rata asupan gizi siswa yang tergolong overweight dan obesitas sebelum intervensi baik pada kelompok perlakuan maupun kontrol berkisar antara $\pm 2500 \mathrm{kkal}$, sedangkan setelah intervensi hanya pada kelompok perlakuan yang mengalami penurunan asupan kalori yang berkisar $\pm 2400 \mathrm{kkal}$.

Hal ini sejalan dengan penelitian Nurmasyita (2015) yang menyatakan bahwa pengetahuan gizi remaja kelebihan berat badan dapat menurunkan Tingkat Kecukupan Energi, Tingkat Kecukupan Protein, persentase asupan karbohidrat, persentase asupan lemak dan meningkatkan asupan serat ${ }^{-}$.

intervensi gaya hidup yang diberikan kepada siswa yang tergolong dan obesitas pada saat penelitian tidak begitu berpengaruh secara bermakna terhadap perubahan aktivitas siswa yang tergolong dan obesitas baik pada kelompok perlakuan maupun kelompok kontrol.

Intervensi gaya hidup merupakan salah satu upaya yang direncanakan sebagai upaya dalam pencegahan obesitas terhadap siswa yang tergolong dan obesitas di SMP Khadijah Kota Makassar tahun 2017. Satu bulan diharapkan terjadi delapan kali pertemuan dengan hasil sesuai harapan.

Namun, pada saat penelitian jadwal pertemuan yang dilaksanakan tidak seperti yang direncanakan sebelumnya dikarenakan kesibukan di tempat penelitian yang bertepatan dengan ujian serta berdekatan dengan waktu Ramadhan, sehingga pertemuan cukup sulit dilakukan.

Meskipun dengan keterbatasan yang ada, peneliti tetap menyesuaikan waktu dalam melakukan pertemuan tersebut. Setiap pertemuan peneliti memberikan materi panduan aktivitas fisik yang terangkum dalam media leaflet dan modul. Intervensi dilakukan di sekitar wilayah sekolah karena tempat konseling diserahkan 
kepada subjek penelitian untuk menentukan agar tercipta suasana yang nyaman. Intervensi melalui edukasi membuktikan peningkatan pengetahuan untuk meningkatkan kesehatan khususnya mencegah obesitas dikalangan remaja $\mathrm{i}^{\underline{11}}$.

\section{KESIMPULAN DAN SARAN}

Penelitian ini menyimpulkan bahwa Intervensi gaya hidup dapat memberikan perubahan yang cukup terhadap status gizi, pola makan, asupan gizi, aktivitas fisik siswa. Penelitian ini merekomendasikan bahwa Prevalensi obesitas pada remaja diharapkan bisa menurun dengan adanya kerjasama berbagai pihak dalam mengupayakan intervensi edukasi gizi terkait dengan gaya hidup terhadap pencegahan obesitas. Pola makan remaja diharapkan bisa membaik dengan memilih jenis makanan yang sehat serta mengatur frekuensi makan dan porsi makannya dengan benar. Asupan gizi remaja diharapkan bisa terkontrol dengan menerapkan pola makan yang benar. Aktivitas fisik pada remaja diharapkan bisa lebih aktif dengan adanya bantuan pihak sekolah dalam memberikan porsi gerakan yang lebih dalam kegiatan olahraga pada anak dan obesitas. Masih banyak faktor yang dapat menyebabkan terjadinya dan obesitas seperti dari aspek sosial ataupun ekonomi. Upaya pencegahan obesitas bisa dilakukan dengan melakukan pendekatan terhadap faktor penyebabnya, sehingga diharapkan adanya penelitian lebih lanjut tentang hal tersebut.

\section{DAFTAR PUSTAKA}

1. W. obesity 2008. Prevalence of obesity, ages. 20.

2. WHO EC. Appropriate body-mass index for Asian populations and its implications for policy and intervention strategies. Lancet (London, England). 2004;363(9403):157.

3. de Ferranti SD, Rodday AM, Mendelson MM, Wong JB, Leslie LK, Sheldrick RC. Prevalence of familial hypercholesterolemia in the 1999 to 2012 United States National Health and Nutrition Examination Surveys (NHANES) clinical perspective.
Circulation. 2016;133(11):1067-1072.

4. Penelitian B. Riset Kesehatan Dasar 2013.(2013). Kementrian Kesehatan RI. 2017.

5. Depertemen Gizi dan Kesehatan Masyarakat FKM UI. Gizi dan Kesehatan Masyarakat (Edisi Revisi). Depok: PT Raja Grafindo Persada.; 2014.

6. Nurmasyita $\mathrm{N}$, Widjanarko $\mathrm{B}$, Margawati A. Pengaruh intervensi pendidikan gizi terhadap peningkatan pengetahuan gizi, perubahan asupan zat gizi dan indeks massa tubuh remaja kelebihan berat badan. JURNAL GIZI INDONESIA. 2016;4(1):38$\underline{47 .}$

7. McNeil J, Cameron JD, Finlayson G, Blundell JE, Doucet É. Greater overall olfactory performance, explicit wanting for high fat foods and lipid intake during the mid-luteal phase of the menstrual cycle. Physiology \& behavior. 2013;112:84-89.

8. Khodijah D, Lukman E, Munigar M. Obesitas dengan kualitas hidup remaja. Jurnal Health Quality. 2013;3(2):69-140.

9. Nicholls L, Lewis AJ, Petersen S, Swinburn B, Moodie M, Millar L. Parental encouragement of healthy behaviors: adolescent weight status and health-related quality of life. BMC public health. 2014;14(1):369.

10. Suriah S, Citrakesumasari C, Awaluddin A, Yani A. Edukasi Bagi Calon Pengantin Tentang Anemia Gizi dan Kurang Energi Kronik di Kota Parepare. MPPKI (Media Publikasi Promosi Kesehatan Indonesia): The Indonesian Journal of Health Promotion. 2018;1(1):25-31.

11. Yani A, Suriah S, Jafar N. Pengaruh SMS Reminder Terhadap Perilaku Ibu Hamil Mengonsumsi Tablet Fe. Media Kesehatan Masyarakat Indonesia. 2017;13(1):12-20. 